\title{
Analysis of Mathematical Content Knowledge of Elementary Teachers in Lampung Utara Regency: A Baseline Study
}

\author{
Budi Poniam ${ }^{1}$ \\ ${ }^{1}$ Sampoerna University \\ Email: budi.poniam@sampoernauniversity.ac.id
}

\begin{abstract}
According to TIMSS 2015 and PISA 2018 reports, Indonesian students' knowledge and skills of mathematics are still far from adequate compare to other countries. Therefore, the efforts to improve the condition need to be done, not just by government but also Indonesian society. Gerakan Nasional Berantas Buta Matematika (GernasTastaka, 2018) is one new movement in Indonesian society that shows its concern and effort. This baseline study aims to describe and analyze the mathematical content knowledge of 100 elementary teachers from Lampung Utara regency that joined the workshop of mathematics teaching and learning which was developed and facilitated by team from Gernas Tastaka. The eight-question multiple-choice pre-test covers Number and Operation, Measurement, Data Analysis, and Probability. Each question is related to specific mathematical content knowledge and skill that are supposed to be mastered by grade 6 students. The quantitative descriptive for each question was conducted to give more details on specific mathematical content knowledge. The result displays that only $36 \%$ of the participants can answer correctly $50 \%$ of the questions. The low competency of teachers gives impact to their students' achievement. It is correspondent with the data from Indonesian National Assessment Program (INAP, 2012); mathematics competency of elementary students in Lampung province is below Indonesian national level. One of the teachers' competencies is their mastery of content knowledge. This study recommends that future developmental workshops/ program for the participants must cover all mathematical content knowledge and skills of elementary level. Besides that, detailed data of participants should be provided in order to attain more reliable analysis.
\end{abstract}

Keywords:

\section{INTRODUCTION}

Compare to other countries, the level of Indonesian students' mathematical knowledge and skill is very low. According to TIMSS 2015 report, Indonesia is the $6^{\text {th }}$ ranking from bottom from total 49 participant countries (Grade 4 students) and PISA 2018, the $7^{\text {th }}$ ranking from bottom out of total 79 participant countries (entities). This condition needs to be improved, not just by Indonesian government, but also Indonesian society, especially educational institutions, communities, and movements. In 2018, a new movement was initiated by some mathematics lecturers and teachers in Indonesia. Its name is Gernas Tastaka. Gernas Tastaka aims to improve the achievement of Indonesian students in mathematics through several programs. One of the major programs is designed to improve the quality of mathematics teachers in facilitating students' mathematics leaning in elementary schools. Part of the program is the development and facilitation of mathematics workshops for elementary school teachers. In the workshop, teachers are assisted in 
enhancing their mathematical content knowledge and mathematics learning strategies. The mathematical content knowledge that is planned to be enhanced refers to the basic competencies of mathematical knowledge and skills which are stated in Indonesia's mathematics curriculum for elementary school (Kurikulum Nasional 2013 (Revisi 2018) Sekolah Dasar).

Besides the strategies of teaching and learning mathematics, the workshop emphasizes on developing teachers' mathematical content knowledge because as mathematical content knowledge is a core component of professional competence, it systematically impacts the quality of teachers' instruction and, in turn, their students' learning progress and achievements (Baumert et al., 2010). Glenda Lappan (1999), NCTM President 1998-2000, wrote in her article "Knowing What We Teach and Teaching What We Know"

"Our own content knowledge affects how we interpret the content goals we are expected to reach with our students. It affects the way we hear and respond to our students and their questions. It affects our ability to explain clearly and to ask good questions. It affects our ability to approach a mathematical idea flexibly with our students and to make connections. It affects our ability to push each student at that special moment when he or she is ready or curious. And it affects our ability to make those moments happen more often for our students."

This baseline study is conducted as a respond to the request by the program development team of Gernas Tastaka. It aims to describe and analyze the mathematical content knowledge of elementary teachers from Lampung Utara regency that joined the workshop of mathematics teaching and learning which was developed and facilitated by team from Gernas Tastaka in Kotabumi, March $23^{\text {rd }} 2019$. The development team wants to know the distribution of the participants' achievement, the average score, the most difficult and easiest questions, the hypothetical reasons that the participants gave the incorrect answers and the recommendation for further development of future pre-test. The result of this baseline study will also be used as a reference to develop further programs for developing and enhancing teachers' mathematical knowledge and skills.

\section{LITERATURE REVIEW}

Ball, Thames, and Phelps (2008) defined mathematical content knowledge (MCK) as the mathematical knowledge and skill used in settings other than teaching. It is used in a wide variety of settings, not unique to teaching. According to them, MCK is needed for mathematics teachers to do their regular duties of teaching mathematics to students. It is the basic teacher competency. Wu (2017) shared the same belief when he mentioned that "Broadly speaking, this knowledge should enable teachers to teach procedural knowledge as well as the reasoning that supports it." (page 10). The failure to provide MCK to mathematics teachers has "indirectly forced school students to memorize things that are unreasonable and incoherent, and therefore ultimately unlearnable."

This belief is supported by several research. Math and Science Partnership (MSP) Knowledge Management and Dissemination Project published a large-scale literature review based on a number of research studies. The review concludes that teachers' MCK influences on their professional practice and their students' achievement. It influences teachers' professional practice. Teachers with stronger MCK show better performances in their classroom instruction practice, their implementation of mathematics curriculum materials, and their professional community building. These better performances show a significant positive relationship with their students' achievement in mathematics learning. 
Therefore, one approach to improve students' achievement is to improve teachers' mathematical content knowledge.

\section{METHOD}

In order to improve teachers' mathematical content knowledge, Gernas Tastaka team developed a eight-question multiple choice pre-test covers Number and Operation, Measurement, Data Analysis, and Probability to assess the participants' mathematical content knowledge before attending the workshop. Each question is related to some specific mathematical content knowledge and skill that are supposed to be mastered by grade 6 students. The pre-test was developed by using multiple choice questions because it would be used to assess many participants. Moreover, based on the team's experience dealing with elementary school teachers in many parts of Indonesia, teachers tend to dislike essay problems as the pre-test of workshop. Therefore, Gernas Tastaka team using multiple choice questions in the pre-test for practical reason.

There were total of 100 elementary teachers from Lampung Utara regency as participants of the workshop. So, there were 100 sets of answers as data for this baseline study. This baseline study uses quantitative data of participants' answers. The numbers of correct answers that each participant gave are used to determine average score and distribution of correct answers. The number of correct answers for each question is used to determine the easiest and most difficult questions. By mapping the mathematical content knowledge (competencies) that related to each question and linking it to the largest number of incorrect answers, the hypothetical reasons that the participants gave the incorrect answers are described. Based on the analysis and finding, a recommendation is given.

\section{RESULT AND DISCUSSION}

\section{Number of Participants with Correct Answers}

Number of the participations that can correctly answer the certain number of questions is shown in Figure 1 (in percentage). As the result displays that only $36 \%$ of the participants can answer correctly more than or equal to four, out of eight questions. The percentage is very low. It is less than $50 \%$ of the participants that can answer correctly $50 \%$ of the questions. The average number of correct answers is 3.42 out of 8 questions or $42.75 \%$. Even though this research was not designed to determine the mathematical content knowledge competency of elementary teachers in Lampung Utara regency as a population, the result shows consistency with the data from Teachers' Competency Test (Uji Kompetensi Guru (UKG)) of elementary teachers in Lampung Utara regency. The test was conducted by Ministry of Education and not focused on mathematical content knowledge but the whole aspects of being a professional teacher. The average score of the test for elementary teachers in Lampung Utara regency (47.19 out of 100) is below the average score of Lampung province (average score 50.23 less than national level) and the second lowest compares to other regencies and municipalities in Lampung Province (total number 16) (KEMENDIKBUD, 2019). 
The low competency of teachers gives impact to their students' achievement. It is correspondent with the data from Indonesian National Assessment Program (INAP, 2012); mathematics literacy of elementary students in Lampung province is below Indonesian national level. There are three categories of students' achievement: poor, adequate, and good. Compares to the data (\% of students) for national level $(77.13,20.58,2.29$ respectively), the achievement of Lampung province's students is lower $(80,49,18.4,1.11)$

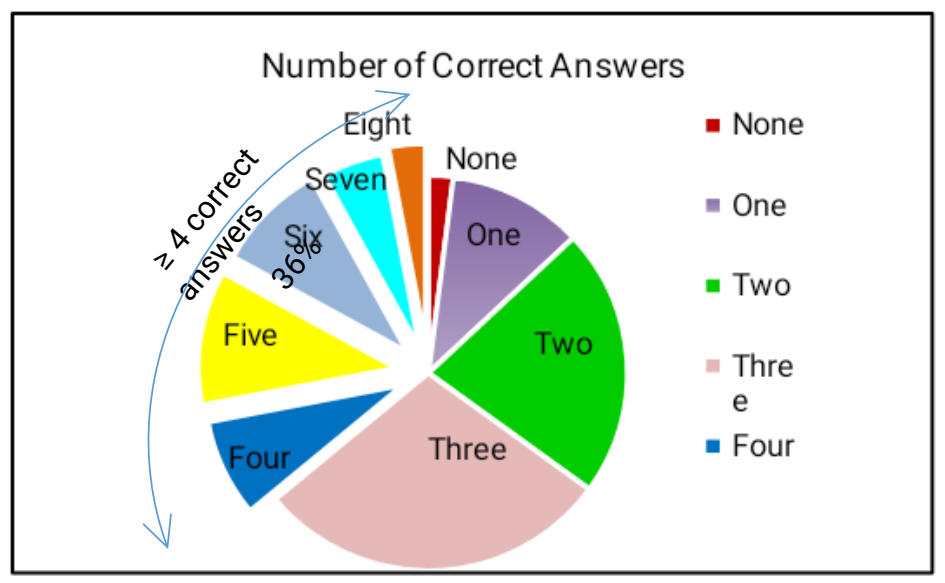

(INAP, 2012).

FIGURE 1. Number of Correct Answers

There is an interesting finding. There are two participants that could not answer all the questions correctly. One of them did not answer at all, he/she just wrote the grade of his/her class (Grade 1). Some of the participants said to the facilitator that the questions were difficult for them because they were just lower grade teachers (grade 1-3). In most of the schools, especially in public schools, teachers tend to teach the same grade level for years. Even some teachers teach only one grade level along their career as teachers. The teachers that have experiences of teaching all grade levels (1-6) are very rare. By having experiences of teaching all grade levels, each elementary teacher can have the opportunity and challenges in mastering all mathematical content knowledge and skills that are supposed to be mastered by grade 6 students. The teachers can relate each mathematical content knowledge and skills that is gradually developed in each grade level. It is important for teachers to see the whole picture of mathematics curriculum so they can design the learning process in each grade level more meaningful and effectively (Skemp, 1989).

The Mapping of the Mathematical Content Knowledge of the Questions

The questions and the mathematical content knowledge that is needed to answer each question correctly are shown in Table 1 . The questions of the pre-test are originally written in Bahasa Indonesia. They are translated into English for this paper-writing purpose. The mathematical content knowledge is referred to the basic competencies of knowledge and skill (Kompetensi Inti Pengetahuan dan Kompetensi Inti Keterampilan) in Indonesia's mathematics curriculum for elementary school (Kurikulum Nasional 2013 (Revisi 2018) Sekolah Dasar).

TABLE 1. Questions and Competencies

\begin{tabular}{cc}
\hline No. Question & $\begin{array}{c}\text { Basic Competencies of } \\
\text { Knowledge and Skill }\end{array}$ \\
\hline
\end{tabular}




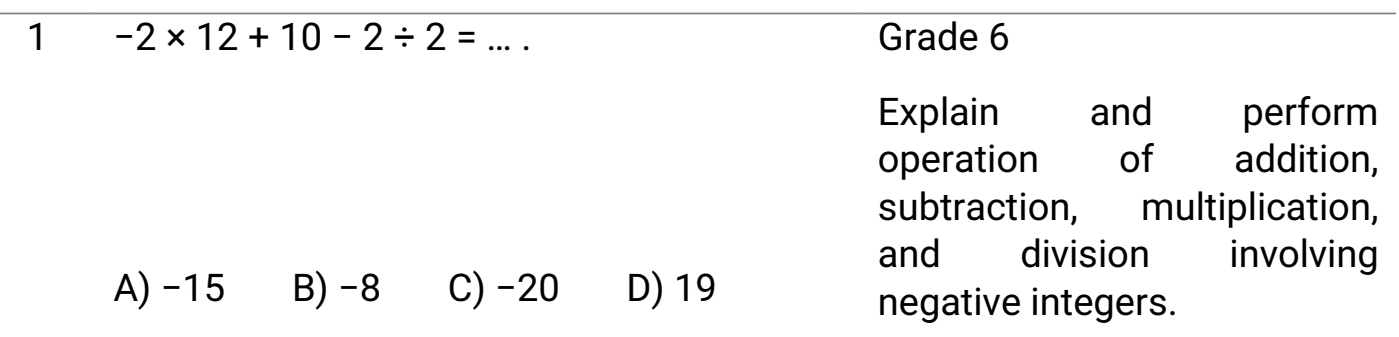

Explain and perform computations that comprise different arithmetic operations involving whole numbers, fractions, and/or decimals by using order of operation.

\section{A ribbon of length $2 \mathrm{~m}$ is cut into three pieces. The first piece has the length of $0.7 \mathrm{~m}$, the second piece $0.45 \mathrm{~m}$. The third piece has the length of ... $\mathrm{m}$.}

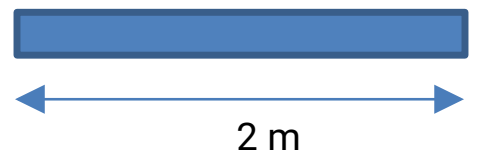

\section{Grade 4}

Solve the problems of estimation of sums, differences, product, and quotient of two whole numbers, fractions, and decimals.
A) 1.95
B) 0.85
C) 0.52
D) 0.48 
3 The ratio of $1.25: 10$ can also be represented as the ratio of .... .
Grade 3

Solve the problems that are related to scale (ratio) in map.

\section{Grade 4}
A) $1: 8.5$
B) $1: 8$
C) $1: 6.5$
D) $1: 5$
Identify several forms of fractions (simple, compound/ mixed, decimal, and percentage) and the relation among them.

Grade 5

Explain and perform multiplication and division involving fractions and decimals.
4 If 1 inch $=2.54 \mathrm{~cm}$ then $254 \mathrm{~cm}$ equals to ... inch(es).

A) 0.01

B) 100

C) 254

D) 645.16

\section{Grade 3}

Describe and determine the relation among standard units for length, mass, and time that are commonly used.

\section{Grade 4}

Solve the problems of estimation of sums, differences, product, and quotient of two whole numbers, fractions, and decimals.

5 A glass aquarium is made in the shape of an open block (open-top cuboid/rectangle prism). Its base has length of $6.0 \mathrm{dm}$ and width of $2.5 \mathrm{dm}$. Its height is $4 \mathrm{dm}$. The area of glasses that is needed to construct the aquarium is ... $\mathrm{dm}^{2}$.

\section{Grade 4}

Solve the problems that are related to perimeter and area of squares, rectangles, and triangles including involvement of power of two 


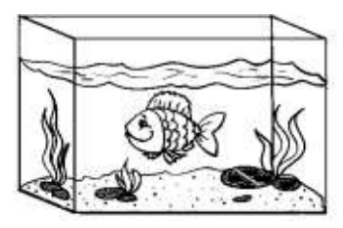

and square root of two.
A) 49
B) 60
C) 83
D) 98

6 The perimeter of the plane that is shown in Grade 3

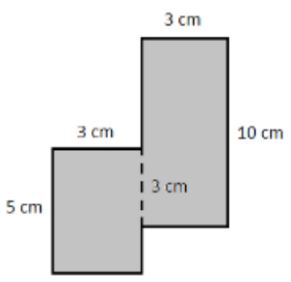

Present and solve the problems that are related to perimeter of planes (flat surfaces).

the picture has the length of ... $\mathrm{cm}$.
A) 42
B) 34
C) 27
D) 36

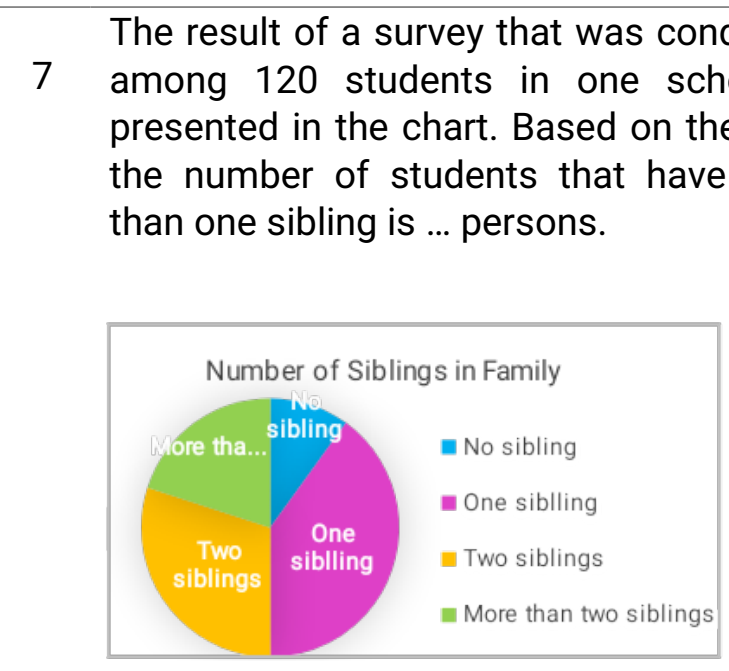

\section{Grade 5 \\ Explain data presentations that are related to students and compare the data to the data of their surrounding in lists, tables, pictogram, bar chart, or line chart.}
A) 60
B) 50
C) 48
D) 40 
8 We want to make numbers of hundreds that consist of numeral 1,2 , and 3 with condition that the repetition of the numerals is not applicable. The number of all possible numbers is ... .
A) 9
B) 6
C) 3
D) 2

Grade 1

Present whole numbers until 99 that are corresponding to the number of objects in a collection.

Read and present whole numbers and their numerals based on place value by using concrete model.

Six out of eight questions (75\%) are corresponding to the competencies of grade 4-6. Some questions need creative mind to answer them correctly because they are related to the combination of several competencies. Those questions cannot be answered by applying a formula or an algorithm, unless new formulas or algorithms are invented for the certain condition in each question. Besides that, other basic skills are needed to answer the questions, such as reading and comprehension skills of mathematical texts, high order thinking skills (applying, analyzing, and creating). 


\section{Analysis of Participants' Answers}

Figure 2 displays the total number of participants' answers (A or B or C or D or blank/other answers) for each question. The participants' answers for each question are presented upon its number and correctness. Q\#2 has the largest percentage of correct answer (74\%) (the easiest question) and Q\#5 has the smallest percentage (15\%) (the most difficult question). Only one question has the percentage more than $50 \%(\mathrm{Q} \# 2)$.

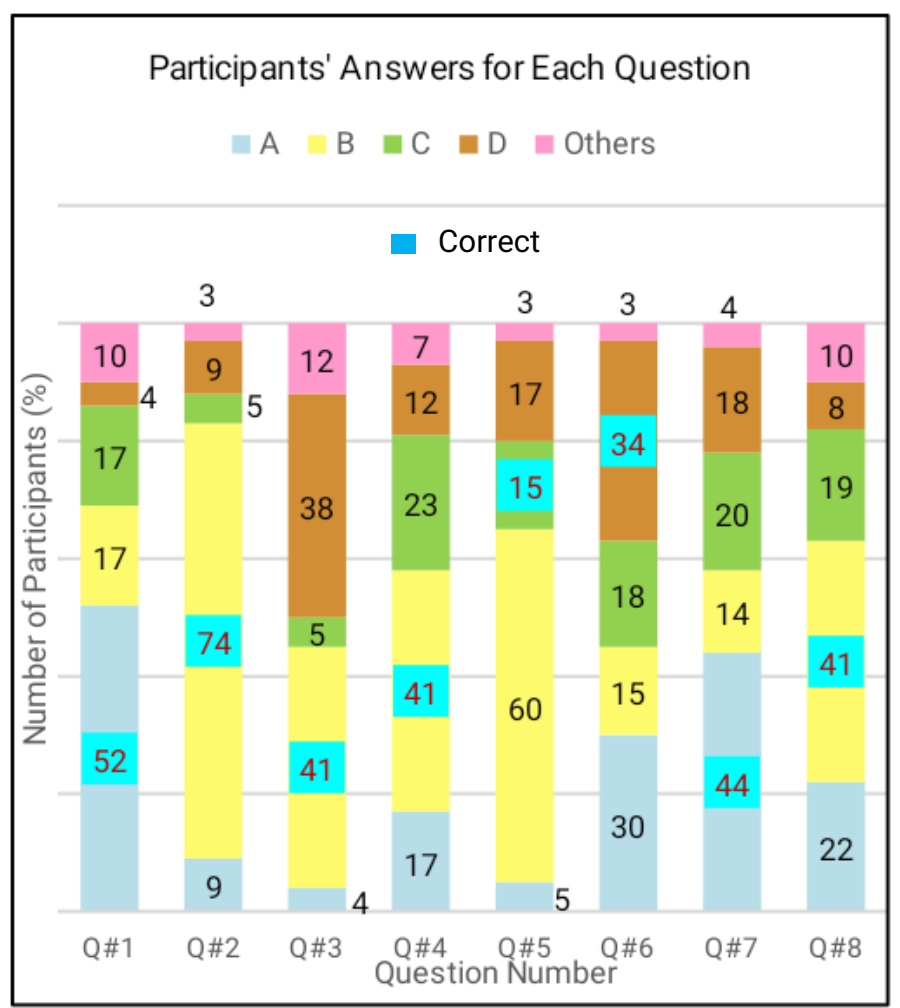

FIGURE 2. Participants' Answers for Each Question

Based on the data in Table 1 and Figure 2, the analysis of the hypothetical reasons that the participants cannot answer each question correctly is made and presented in Table 2, except for Q\#2 due to the small percentage $(<10 \%)$ for each of its incorrect answers. The incorrect answers that are selected to be analysed for each question are the ones that have the largest percentage among other incorrect answers for each question. The possible reasons are suggested by assuming that the participants' incapability to answer the question correctly is directly related to the lack of the competencies that are displayed in Table 1.

TABLE 2. Hypothetical Reasons of Incorrect Answers

\begin{tabular}{clll}
\hline Question & Incorrect Answer & \multicolumn{1}{c}{ Possible Reasons } \\
\hline Q\#1 & B. -8 & $(17 \%)$ & $(((-2 \times 12)+10)-2): 2=-8$. \\
& & $\begin{array}{l}\text { The participants can compute with integer but } \\
\text { cannot apply order of operation. Order of } \\
\text { operation is not only applied in operations on } \\
\text { numbers but also on variable in algebra. }\end{array}$ \\
\hline
\end{tabular}




\begin{tabular}{|c|c|c|}
\hline & & $7-7 x \neq(7-7) \times x$ \\
\hline & C. $-20(17 \%)$ & $-2 \times(12+10-2): 2=-20$. Idem \\
\hline Q\#3 & D. $1: 5$ (38\%) & $\begin{array}{l}\text { Participants might not understand the meaning } \\
\text { of "ratio" and "represented" or cannot figure } \\
\text { out the relation between division using } \\
\text { decimals with simple fraction. }\end{array}$ \\
\hline \multirow[t]{2}{*}{ Q\#4 } & C. $254 \quad(23 \%)$ & 1 inch $=2.54 \mathrm{~cm} ; 254 \mathrm{~cm}=254$ inches? \\
\hline & & $\begin{array}{l}\text { Participants lack the number sense or do not } \\
\text { understand the relation among standard units } \\
\text { for length. }\end{array}$ \\
\hline \multirow[t]{2}{*}{ Q\#5 } & A. $60 \quad(60 \%)$ & $6 \mathrm{dm} \times 2,5 \mathrm{dm} \times 4 \mathrm{dm}=60 \mathrm{dm}^{3}$ (volume) \\
\hline & & $\begin{array}{l}\text { The question is about area. Participants might } \\
\text { misread the question or they just cannot apply } \\
\text { their knowledge in real situation. }\end{array}$ \\
\hline \multirow[t]{2}{*}{ Q\#6 } & A. $42 \quad(30 \%)$ & $2 \times(10+3)+2 \times(5+3))=42$ \\
\hline & & $\begin{array}{l}\text { Participants might apply the formula of } \\
\text { computing perimeter of a plane without } \\
\text { carefully investigating the condition stated in } \\
\text { the question or not understand the meaning of } \\
\text { the dashed line in the diagram. }\end{array}$ \\
\hline \multirow[t]{2}{*}{ Q\#7 } & C. $48 \quad(20 \%)$ & $40 \% \times 120=48$. (one sibling) \\
\hline & & $\begin{array}{l}\text { Participants might understand the data } \\
\text { presentation in chart but misread the question } \\
\text { (more than one sibling). }\end{array}$ \\
\hline Q\#8 & A. $9 \quad(22 \%)$ & $\begin{array}{l}\text { Participants might not understand the meaning } \\
\text { of numbers of hundreds or they cannot create } \\
\text { numbers of hundreds even know the meaning. }\end{array}$ \\
\hline
\end{tabular}

Hypothetically, participants have difficulties in answering the questions correctly because they lack the basic understanding of some mathematics terms, and/ or the mathematical thinking skill, especially to apply the mathematical concepts and construct the integrated mathematical knowledge and skills; and/ or the skill of reading mathematical texts or questions. The analysis is conducted based on assumption that the participants' answers were related only with the participants' mathematical content knowledge. More data is needed in order to do the comprehensive and reliable analysis, especially data of participants' reasoning in answering the questions; by interviewing some of the participants or each answer must be explained by steps of computation and arguments.

\section{CONCLUSION}

The most difficult question is Q\#5 (only 15\% of participants can answer the question 
correctly) and the easiest question is Q\#2 (74\%). Only one question has the percentage more than $50 \%(\mathrm{Q} \# 2)$. The mathematical content knowledge of the participants of the workshop is needed to develop due to the low performance of the participants in answering the questions of the pre-test. Less than $50 \%$ of the participants (only $36 \%$ ) can answer correctly $50 \%$ the questions. The average number of correct answers is $42,75 \%$. The developmental workshops/ program must cover all knowledge and skills that are required by Indonesia's mathematics curriculum for elementary school (Kurikulum Nasional 2013 (Revisi 2018) Sekolah Dasar) and should be designed in such that the participants can construct their integrated mathematical knowledge and skills, not segmented/ isolated knowledge and skill. Participants' reading skill, especially of mathematical text, should be assessed in order to enhance the skill.

Analysis about the possible correlation between participants' background and their low/high achievement in the pre-test can be done if data of the participants' backgrounds, such as the grade levels that the participants teach, is available. Besides that, important data can be attained by interviewing some participants about their answers. The data can be useful for knowing better the participants' mathematical content knowledge and skills in order to develop and facilitate further workshops more effectively. Unfortunately, the data is not available.

\section{REFERENCES}

Baumert, J., Kunter, M., Blum, W., Brunner, M., Voss, T., Jordan, A., ... Klusmann, U. (2010). Teachers' mathematical knowledge, cognitive activation in the classroom, and student progress. American Educational Research Journal, 47(1), 133-180. doi:10.3102/0002831209345157.

Ball, D. L., Thames, M. H., and Phelps, G. (2008). Content knowledge for teaching: what makes it special? Jurnal of Teacher Education, 59 (5), 389-407, Sage Publications.

Hasil Indonesian National Assesment programme (INAP). (2012). Retrieved from https://puspendik.kemdikbud.go.id/inap-sd/kategori.

KEMENDIKBUD. (2019). Retrieved from https://npd.kemdikbud.go.id/?appid=ukg.

Lappan, G. (1999). Knowing what we teach and teaching what we know - National Council of teachers of mathematics. Retrieved from https://www.nctm.org/News-andCalendar/Messages-from-the-President/Archive/Glenda-Lappan/Knowing-What-We -Teach-and-Teaching-What-We-Know/.

Math and Science Partnership (MSP) Knowledge Management and Dissemination Project. Why teachers' mathematics content knowledge matters: a summary of studies. Retrieved from http://www.mspkmd.net/pdfs/blast22/3b2.pdf.

Mullis, I. V., Martin, M. O., Foy, P., \& Hooper, M. (2016). TIMSS 2015 International Results in Mathematics. Retrieved from TIMSS \& PIRLS website: https://timssandpirls.bc.edu/isc/publications.html.

Schleicher, A. (2019). PISA 2018 Insight and Interpretations. Retrieved from OECD website: https://www.oecd.org/pisa/PISA\%202018\%20Insights\%20and\%20Interpretations\% 20FINAL\%20PDF.pdf.

Skemp, R. R. (1989). Mathematics in the Primary School. Routledge.

$\mathrm{Wu}, \mathrm{H}$. H. (2018). The content knowledge mathematics teachers need. Mathematics Matters in Education, Yeping Li, W. James Lewis, and James Madden. (Eds.) 2018, 43-91, Springer, Dordrecht. 